\title{
Protection of Trade Secrets in Outer Space Activity: A Study in Ukrainian Law
}

\author{
Leonid Daderko \\ Ph.D., Associate Professor, \\ Open International University of Human Development "Ukraine" \\ (Kyiv, Ukraine) \\ E-mail: sipl@email.ua
}

In 1993, the paper "Protection of Trade Secrets in Outer Space Activity: A Study in Federal Preemption" by leading researcher in the field of intellectual property Dan L. Burk was published. The Dan L. Burka paper testifies that the legal settlement of the problem of trade secrets in outer space activities in American law was at the time still at the end of the twentieth century. The further development of space law allows us to conclude that this problem has not lost its relevance. It is open and requires further development. In the paper the author considers issues of the content of information that is trade secrets in accordance with Ukrainian legislation. Attention is paid to the content of information that is trade secrets.

Keywords: trade secrets; confidential secrets; outer space activities; space law

\section{Захист комерційних таємниць у космічній діяльності: дослідження в українському законодавстві}

\author{
Дадерко, Леонід Федорович
}

кандидат юридичних наук, доцент, Відкритий міжнародний університет розвитку людини «Україна»

(Київ, Україна)

В 1993 роиі вийшла стаття провідного дослідника інтелектуальної власності Ден Л. Бурка (Dan L. Burk) «Захист комериійних таємниць укосмічній діяльності: дослідження на федеральному рівні». Стаття Ден Л. Бурка засвідчує, щуо правове врегулювання проблеми комериійних таємниць у космічній діяльності в американському законодавстві була на часі ще на при кіниі ХХ століття. Подальший розвиток космічного права дозволяє зробити висновок, щэо ия проблема не втратила актуальності. Вона є відкритою і потребує подальших розробок. У статті автором розглянуті питання змісту інформації, яка становить комериійну таємницчю відповідно украйнського законодавства. Увагу приділено змісту інформації, яка становить комериійну таємницю.

Ключові слова: комериійна таємниия; конфідениійна таємниия; космічна діяльність, космічне право

(C) Daderko, Leonid, 2018 
Received: January 26, 2018; accepted: February 20, 2018

Advanced Space Law, Volume 1, 2018: 24-32.

https://doi.org/10.29202/asl/2018/1/3

\section{Постановка проблеми}

В 1993 році вийшла стаття провідного дослідника інтелектуальної власності в американській юридичній академії Ден Л. Бурка (Dan L. Burk) «Захист комерційних таємниць у космічній діяльності: дослідження на федеральному рівні» [Burk, 1993]. Стаття Ден Л. Бурка засвідчує, що правове врегулювання проблеми комерційних таємниць у космічній діяльності в американському законодавстві була на часі ще на при кінці XX століття. Подальший розвиток космічного права дозволяє зробити висновок, що ця проблема не втратила актуальності. Вона є відкритою і потребує подальших розробок. Розглянемо питання змісту інформації, яка становить комерційну таємницю відповідно українського законодавства.

\section{Результати дослідження}

Питання змісту інформації, яка становить комерційну таємницю, викликає дискусію. Надмірне «втаємничення» може викликати втрату клієнтів, а це нанесе шкоду діяльності фірми чи організації.

За останній час відбулися значні законодавчі зміни в правовому регулюванні захисту комерційної таємниці. Зокрема, відповідальність за розголошення комерційної таємниці передбачає Цивільний кодекс України, Господарський кодекс України, Кримінальний кодекс України, а також Закон України «Про інформацію» [Закон України, 1992].

Для покрашення якості й ефективності застосування норм юридичної відповідальності доцільно було б прийняти нормативний акт, у якому були б визначені всі види таємниці: комерційна таємниця, конфіденційна таємниця, державна таємниця; їх поняття, ознаки й розмежування одна від одної, а також види й межі покарань за їх розголошення. Це б дало змогу ефективніше вести боротьбу із цими злочинами.

Сьогодні в Україні, як і в інших країнах світу, у процесі підприємницької діяльності, під час створення нових технологій, у результаті інтелектуальної праці виникають насичені найрізноманітнішими відомостями інформаційні об'єкти, що мають комерційну цінність. Це можуть бути методики робіт, перспективні технічні рішення, результати маркетингових досліджень тощо, націлені на досягнення підприємницького успіху.

Інформація стала першоосновою життя сучасного суспільства, предметом і продуктом його діяльності, а процес створення, накопичення, збереження, передачі й обробки у свою чергу стимулював прогрес у галузі знарядь ії виробництва, що включає електронно-обчислювальну техніку, засоби телекомунікації та системи супутникового зв'язку. У зв'язку з новими інформаційними досягненнями державні кордони фактично стають прозорими для обігу інформації. При цьому чим більше зазначена галузь залучається до комерційного обігу, тим більше виникає потреба в захисті інтересів власників комерційної таємниці. 
Проблема захисту комерційної таємниці має багато аспектів, серед яких найважливішими є визначення правового положення комерційної таємниці як соціального ресурсу, юридичне закріплення права на комерційну таємницю та створення правових гарантій реалізації цього права, регулювання відносин, які виникають у сфері обігу комерційної таємниці.

Необхідно визнати, що в країнах світу, де використовуються інформаційні об'єкти, які представляють комерційну цінність, немає єдиного підходу до визначення поняття такої інформації. Застосовуються різні визначення: «ділові секрети», «виробничі секрети», «торгівельні секрети», «конфіденційна інформація», «комерційна таємниця» тощо.

Питання щодо змісту інформації, яка становить комерційну таємницю, завжди викликало багато дискусій, наприклад щодо кореляції понять комерційної таємниці (конфіденційної інформації й інформації взагалі) та інтелектуальної власності. Інформація, згідно із законодавством України, є об'єктом права власності, проте вона одночасно може бути й об’єктом права інтелектуальної власності.

Закон України «Про інформацію» під поняттям «інформація» розуміє документовані або публічно оголошені відомості про події та явища, що відбуваються в суспільстві, державі й навколишньому природному середовищі.

Деталізоване визначення поняття «інформація» знаходимо в Законі України «Про захист економічної конкуренції»: «відомості в будь-якій формі й вигляді та збережені на будь-яких носіях (у тому числі листування, книги, помітки, ілюстрації (карти, діаграми, органіграми, малюнки, схеми тощо), фотографії, голограми, кіно-, відео-, мікрофільми, звукові записи, бази даних комп'ютерних систем або повне чи часткове відтворення їх елементів), пояснення осіб та будь-які інші публічно оголошені чи документовані відомості» [Закон України, 2001].

3 правової точки зору комерційну таємницю часто пов’язують із засобами захисту від неякісної конкуренції в межах реалізації права на інтелектуальну власність. Це положення постає зі змісту пункту VIII статті 2 Конвенції про заснування Всесвітньої організації інтелектуальної власності, яка була підписана в Стокгольмі 14 липня 1967 р. та змінена 2 жовтня 1979 р., учасником якої був колишній СРСР, а сьогодні є Україна.

Що стосується використання понять «ділові секрети», «виробничі секрети», «торгівельні секрети» тощо, то в Україні законодавцем визначено, що всі ці види секретів можна об’єднати в один узагальнюючий термін «комерційна таємниця», що й знайшло своє закріплення на законодавчому рівні.

Згідно зі статтею 155 Господарського кодексу України серед об’єктів прав інтелектуальної власності у сфері господарювання $є$ й комерційна таємниця [Господарський кодекс, 2003]. Зокрема, відомості, пов’язані з виробництвом, технологією, управлінням, фінансовою й іншою діяльністю суб'єкта господарювання, що не є державною таємницею, розголошення яких може завдати шкоди інтересам суб'єкта господарювання, можуть бути визнані його комерційною таємницею. Проте наявність у складі назви «комерційна таємниця» слова «таємниця» вносить певну неоднозначність у тлумачення цього поняття. Згідно зі статтею 20 Закону України «Про інформацію» інформація 3 обмеженим доступом поділяється на конфіденційну й таємну. При цьому конфіденційна інформація — це відомості, які знаходяться у володінні, користуванні або розпорядженні окремих фізичних чи юридичних осіб і поширюються за їхнім бажанням відповідно до передбачених ними умов. До таємної належить інформація, що містить відомості, які 
становлять державну або іншу передбачену законодавством таємницю, розголошення якої завдає шкоди особі, суспільству й державі.

Таким чином, комерційну таємницю залежно від змісту відомостей, які вона містить, можна розглядати як конфіденційну інформацію, так і іншу передбачену законодавством таємницю, крім державної таємниці.

Склад та обсяг відомостей, що становлять комерційну таємницю, визначаються суб'єктом господарювання відповідно до законодавства. Згідно з Постановою Кабінету Міністрів України «Про перелік відомостей, що не становлять комерційної таємниці» не можуть бути віднесені до комерційної таємниці [Постанова, 1993]:

1. Установчі документи, документи, що дозволяють займатися підприємницькою чи господарською діяльністю та її окремими видами;

2. Інформація за всіма встановленими формами державної звітності;

3. Дані, необхідні для перевірки обчислення й сплати податків та інших обов'язкових платежів;

4. Відомості про чисельність і склад працюючих, їхню заробітну плату в цілому та за професіями й посадами, а також наявність вільних робочих місць;

5. Документи про сплату податків та обов'язкових платежів;

6. Інформація про забруднення навколишнього природного середовища, недотримання безпечних умов праці, реалізацію продукції, що завдає шкоди здоров’ю, а також інші порушення законодавства України та розміри заподіяних при цьому збитків;

7. Документи про платоспроможність;

8. Відомості про участь посадових осіб підприємства в кооперативах, малих підприємствах, спілках, об’єднаннях та інших організаціях, які займаються підприємницькою діяльністю;

9. Відомості, які відповідно до чинного законодавства підлягають оголошенню.

Підприємства, установи й організації зобов'язані подавати перераховані відомості органам державної виконавчої влади, контролюючим і правоохоронним органам, іншим юридичним особам за їх вимогою відповідно до чинного законодавства.

Отже, відомості, які можуть бути віднесені до комерційної таємниці, повинні мати такі ознаки:

1. Не містити державної таємниці;

2. Не наносити шкоди інтересам суспільства;

3. Відноситися до виробничої діяльності підприємства;

4. Мати дієву або потенційну комерційну цінність і створювати переваги в конкурентній боротьбі;

5. Мати обмеження в доступі тощо.

Із цього переліку не потрібно робити висновок про те, що до комерційної таємниці варто відносити значну кількість відомостей. Надмірне «втаємничення» може викликати втрату клієнтів, а отже, прибутку, оскільки умови ринку потребують постійних клієнтів, широкої інформації про діяльність фірми (організації).

Досягнення успіху в підприємницькій діяльності дуже часто пов'язане з використанням комерційної таємниці й неможливістю їі використання конкурентами. Виділяють такі причини, що становлять основу неправомірного використання комерційної таємниці конкурентами:

1. Для поліпшення виробничої й комерційної діяльності організації (конкурента), що протиправно заволоділа комерційною таємницею, підвищення конкуренто- 
спроможності продукції й ефективності виробництва, вибору оптимальної стратегії реалізації продукції та торгових переговорів;

2. Для завдання шкоди власнику комерційної таємниці, протидії реалізації продукції, руйнування виробничих і торгівельних зв'язків; зриву торгівельних переговорів та угод; зниження інвестиційних можливостей, підготовки та розповсюдження неправдивих відомостей про власника комерційної таємниці тощо.

Загальні умови захисту прав інтелектуальної власності, зокрема комерційної таємниці, визначаються Цивільним кодексом України. Реалізація майнових прав інтелектуальної власності на комерційну таємницю забезпечується:

1. Правом на використання комерційної таємниці;

2. Виключним правом дозволяти використання комерційної таємниці;

3. Виключним правом перешкоджати неправомірному використанню комерційної таємниці, у тому числі забороняти таке використання.

Закон України «Про інформацію» визначає, що громадяни, юридичні особи, які володіють інформацією, у тому числі комерційного характеру, одержаною на власні кошти, або такою, яка є предметом їх професійного, ділового, виробничого, банківського, комерційного й іншого інтересу та не порушує передбаченої законом таємниці, самостійно визначають режим доступу до неї, включаючи належність її до категорії конфіденційної, і встановлюють для неї систему (способи) захисту [Закон України, 1992]. Разом із цим, впроваджуючи систему захисту комерційної таємниці, їі власник повинен враховувати економічну доцільність такої системи. Тут важливими стають два моменти:

1. Витрати на забезпечення економічної безпеки повинні бути, як правило, меншими порівняно з можливими збитками;

2. Заходи безпеки мають сприяти підвищенню економічної ефективності підприємництва.

Основними документами для ведення комерційної діяльності підприємством є статут підприємства та установчий договір, зареєстровані у встановленому законодавством порядку. Документами, які регламентують взаємовідносини всередині підприємства, $є$ колективний договір, правила внутрішнього трудового розпорядку й перелік відомостей, які містять комерційну таємницю підприємства.

Статут підприємства — це основний документ, у якому обов'язково повинно бути зафіксовано положення про те, що підприємство має право на комерційну таємницю й організацію її захисту. У статуті повинно бути встановлено, хто визначає порядок захисту комерційної таємниці. Зафіксовані в статуті положення надають підприємству можливість вимагати захисту його інтересів у державному й судовому органі; включати вимоги про захист комерційної таємниці у всі види угод; домагатися відшкодування заподіяної шкоди у випадку викрадення комерційної таємниці; видавати нормативні документи, що стосуються питань охорони комерційної таємниці; створювати структурні підрозділи для захисту своєї комерційної таємниці.

В установчому договорі повинна бути обов'язково зафіксована вимога до учасників товариства щодо необхідності дотримання комерційної таємниці та відповідальності за розголошення такої інформації. У колективному договорі необхідно передбачити взаємні обов'язки адміністрації й колективу працівників підприємства щодо забезпечення збереження комерційної таємниці.

Підкреслимо, що, на відміну від відомих, традиційних для права об'єктів, інформація, зокрема така, що становить комерційну таємницю у космічній діяльності, харак- 
теризується специфічними особливостями та юридичними властивостями, які багато в чому визначають і відношення, які виникають під час іiі обігу між суб'єктами, та характер їх поведінки. До таких особливостей і властивостей можна віднести такі:

1. Інформація під час включення в обіг відокремлюється від автора або власника, упредметнюється у вигляді символів і знаків та внаслідок цього існує окремо й незалежно від автора або власника. Звідси виникає юридична властивість інформації, зокрема можливість виступати як об’єкт, що передається від одного суб'єкта іншому та потребує юридичного закріплення факту іiї приналежності суб'єктам, які беруть участь у такому їі використанні;

2. Після передачі інформації від одного суб'єкта іншому одна й та ж інформація може залишатися в суб'єкта, який передає, та виникати в суб'єкта, який її отримує. Тобто однакова інформація одночасно може належати двом учасникам інформаційних відносин. Це основна відмінність інформації від речі. Юридична властивість інформації в зв'язку із цим — iï фізична невідчужуваність від автора, власника й користувача. Така властивість потребує розробки й застосування до інформації під час іiї використання особливих правових механізмів, які замінюють механізм відчуження речі;

3. Інформація під час включення в обіг документується та відображується на матеріальному носії. Юридична властивість, яка постає із цієї особливості, полягає в єдності інформації й матеріального носія, на якому закріплюється інформація. Ця властивість дає можливість ввести для документованої інформації поняття складної складової речі - інформаційної речі, що складається 3 носія інформації й самої інформації, яка відображена на носії.

Розглядаючи інформацію з точки зору суспільного обігу, необхідно вказати, що інформація повинна бути розглянута у двох аспектах. Як зазначалося вище, загально недоступна інформація має свою комерційну цінність завдяки невідомості третім особам. Відповідно, повинна будуватися й правова охорона такої інформації.

Водночас $є$ загальнодоступна й загальновідома інформація, яка може мати комерційну цінність, що виникає в результаті ії представлення в необхідній для споживача формі та не є результатом творчої праці. Однак для обробки такої інформації потрібні певні витрати. Ця інформація також повинна захищатися. Таким чином, під час правової охорони інформації можливий захист їі змісту й форми.

Умовно виділяють два види охорони інформації, що використовуються в підприємницькій діяльності, тобто два види інформаційної безпеки: пасивну й активну [Андрощук, 2000].

Пасивна охорона характеризується тим, що власник інформації надає їй режим відкритості, доступності для всіх зацікавлених осіб, проте ці особи не можуть використовувати ії в комерційних цілях. Саме власникові належить виключне право дозволяти кому-небудь використовувати цю інформацію. Таку охорону інформації встановлюють патентне й авторське право. Захист інтересів власника інформації у випадку ії несанкціонованого використання реалізується в судовому порядку на підставі законодавства України.

Прикладів інформаційних об'єктів, на які їх власники поширюють пасивну охорону, досить багато: винаходи, корисні моделі, промислові зразки (дизайн), товарні знаки, фірмові найменування, музичні, драматичні, аудіовізуальні, літературні, письмові здобутки різного характеру, комп’ютерні програми, лекції тощо. 
Активна охорона інформації, що більше підходить для охорони комерційної таємниці від несанкціонованого власником використання, пов'язана з тим, що власник встановлює певний режим доступу, наприклад обмежує доступ до інформації вузьким колом фахівців із числа персоналу, організує режимні зони на підприємстві, використовує носії інформації, що роблять неможливим несанкціоноване копіювання тощо.

Прикладом інформації, що може підпадати під активну охорону та становити комерційну таємницю, є відомості типу ноу-хау, тобто відомості технічного характеру (режими, методики, технологічні карти тощо), результати різних досліджень, методи управління, а також інформаційні об’єкти, що мають настільки значну комерційну цінність, що власник із міркувань доцільності або безпеки надає цій інформації режим обмеженого доступу.

На сьогодні втратам комерційної таємниці в Україні сприяє безсистемність їі захисту. Спостерігається роз'єднаність зусиль держави та приватних підприємців у забезпеченні цілісності інформації, відсутність у власників комерційної таємниці організаційного досвіду щодо її захисту, недостатність правової підготовки й інформаційної культури.

Під час застосування організаційно-правового механізму захисту комерційної таємниці у космічній діяльності постає низка невирішених питань:

1. Відсутність чіткого визначення поняття «комерційна таємниця» $з$ урахуванням інтересів як юридичних, так і фізичних осіб;

2. Розробки механізму здійснення прав власності на інформацію, віднесеної до комерційної таємниці;

3. Методики визначення її вартості; визначення органу державної виконавчої влади, що буде формувати й реалізовувати державну політику щодо охорони прав на комерційну таємницю тощо.

Що стосується визначення органу державної виконавчої влади, який буде формувати й реалізовувати державну політику щодо охорони прав на комерційну таємницю, Законом України «Про Службу безпеки України» в статті 25 визначено, що до обов'язків Служби безпеки України віднесено, зокрема, сприяння в порядку, передбаченому законодавством, підприємствам, установам, організаціям і підприємцям у збереженні комерційної таємниці, розголошення якої може завдати шкоди життєво важливим інтересам України [Про Службу безпеки, 1992]. Як бачимо, формулювання цієї норми не дозволяє чітко визначити, чи є Служба безпеки України саме тим органом державної виконавчої влади, який буде формувати й реалізовувати державну політику щодо охорони прав на комерційну таємницю, чи ні. Крім того, законодавець не визначає, що розуміється під поняттям «сприяти», а також механізму реалізації цього «сприяння».

\section{Висновки}

Підсумовуючи викладене, необхідно зауважити, що коли інформація стає об’єктом власності, виникають певні питання щодо правомірності ії використання. Це пов'язують 3 тим, що звичайна або інформаційна власність — це певна монополія особи на об'єкт права. Монополія дозволяє отримувати прибутки за дозвіл використовувати об'єкт. Ця можливість - мрія будь-якої структури, як приватної, так і державної. Як підкреслюють деякі науковці, інформація — це об'єкт, який не споживається, який можливо продати безліч разів. Небезпека цього є очевидною, адже монополія - це не тільки право дозволяти за гроші, а й забороняти з примхи. 
Зокрема, у Законі України «Про інформацію» та Законі України «Про захист економічної конкуренції» визначені законодавцем поняття відрізняються. Комерційну таємницю часто пов'язують із засобами захисту від неякісної конкуренції в межах реалізації прав на інтелектуальну власність. Серед об'єктів інтелектуальної власності у сфері господарювання $є$ й комерційна таємниця. Назва «комерційна таємниця», зокрема слово «таємниця», вносить неоднозначність у тлумачення цього поняття. Залежно від змісту відомостей комерційну таємницю можна розглядати як конфіденційну інформацію, так і іншу таємницю, передбачену законодавством, окрім державної таємниці.

\section{Література}

Андрощук, Геннадий. Экономическая безопасность предприятия: защита коммерческой тайны. Київ: Ин Юре, 2000.

Господарський кодекс України: Закон України від 16 січня 2003 р. № 436-IУ II. Відомості Верховної Ради України. 18, 2003. Ст. 144.

Закон України «Про інформацію». Відомості Верховної Ради України (ВВР), 48, 1992 , ст.650. https://zakon.rada.gov.ua/laws/show/2657-12

Закон України «Про захист економічної конкуренції». Відомості Верховної Ради України (ВВP). 12, 2001, № 12, ст.64. https://zakon.rada.gov.ua/laws/show/2210-14

Кримінальний кодекс України: Закон України від 5 квітня 2001 р. № 2341-III. Biдомості Верховної Ради України. 25, 2001. Ст. 131.

Митний кодекс України: Закон України від 13 березня 2012 р. № 4495-УІІІ. Відомості Верховної Ради України. 44-48, 2012. С. 1858. - Ст. 552.

Постанова Кабінету Міністрів Украӥни «Про перелік відомостей, щзо не становлять комериійної таємниці» від 9 серпня 1993 р. № 611. https://zakon.rada.gov.ua/laws/ show $/ 611-93-\% \mathrm{D} 0 \% \mathrm{BF}$

Про службу безпеки: Закон України від 25 березня 1992 р. № 2229-XIIII. Відомості Верховної Ради України. 27, 1992. Ст. 382.

Burk, Dan L. Protection of Trade Secrets in Outer Space Activity: A Study in Federal Preemption. Seton Hall Law Review, 23, 1993: 560-640. https://escholarship.org/uc/ item $/ 5 \mathrm{n} 8170 \mathrm{zb}$

\section{References}

Androshchuk, Hennadyi. Эkonomycheskaia bezopasnost predpryiatyia: zashchyta kommercheskoi tainы. Kyiv: Yn Yure, 2000.

Hospodarskyi kodeks Ukrainy: Zakon Ukrainy vid 16 sichnia 2003 r. № 436-IU II. Vidomosti Verkhovnoi Rady Ukrainy. 18, 2003. St. 144.

Zakon Ukrainy «Pro informatsiiu». Vidomosti Verkhovnoi Rady Ukrainy (VVR), 48, 1992, st.650. https://zakon.rada.gov.ua/laws/show/2657-12

Zakon Ukrainy «Pro zakhyst ekonomichnoi konkurentsii». Vidomosti Verkhovnoi Rady Ukrainy (VVR). 12, 2001, № 12, st.64. https://zakon.rada.gov.ua/laws/show/2210-14

Kryminalnyi kodeks Ukrainy: Zakon Ukrainy vid 5 kvitnia 2001 r. № 2341-III. Vidomosti Verkhovnoi Rady Ukrainy. 25, 2001. St. 131.

Mytnyi kodeks Ukrainy: Zakon Ukrainy vid 13 bereznia 2012 r. № 4495-UIII. Vidomosti Verkhovnoi Rady Ukrainy. 44-48, 2012. S. 1858. — St. 552. 
Postanova Kabinetu Ministriv Ukrainy «Pro perelik vidomostei, shcho ne stanovliat komertsiinoi taiemnytsi» vid 9 serpnia 1993 r. № 611. https://zakon.rada.gov.ua/laws/show/61193-\%D0\%BF

Pro sluzhbu bezpeky: Zakon Ukrainy vid 25 bereznia 1992 r. № 2229-KhIIII. Vidomosti Verkhovnoi Rady Ukrainy. 27, 1992. St. 382.

Burk, Dan L. Protection of Trade Secrets in Outer Space Activity: A Study in Federal Preemption. Seton Hall Law Review, 23, 1993: 560-640. https://escholarship.org/uc/ item $/ 5 \mathrm{n} 8170 \mathrm{zb}$ 